\title{
Priced Separation and Supply-Price Specification of Exports: Evidence from Pakistan
}

\section{Mohammad Afzal*}

\section{Introduction}

Empirical studies of international trade have concentrated on singleequation models to analyse the demand relationship for imports and exports [Houthakker and Magee (1969). Naqvi et al (1983), Bnhmani-Oskooee $(1984,1986)]$. These studies have assumed that the imports and exports price elasticities facing any individual country are infinite or at least large. The assumption of infinite supply price elasticity may be acceptable for the world supply of imports to a single country. Export demand and supply functions have been estimated in a simultaneous equation framework by Khan (1974), Goldstein and Khan (1978). Dunlevy (1980), Arize (1986.1988). Balassa et al [1989]. Anwar (1985), and Khan and Saqib (1993)] for both developed and underdeveloped countries.

Haynes and Stone (1983) argue that previous studies failed to estimate the supply behaviour of both imports and exports not only because of a simultaneity bias but also because quantity rather than price were specified as the dependent variable. They have, based on the evidence of USA and UK trade data for the period 1947-79, found support for a dynamic supply- price model for both exports and imports and no evidence to support dynamic supply-quantity specification for these countries.

Murray and Ginman (1975) argue that the traditional log-linear model of imports in international trade studies is incorrectly specified because the traditional form of the import demand makes the coefficients equal in magnitude but opposite in sign to import price and domestic price indices. They applied the above-suggested form to the Canadian experience for 1950-64.

Both suggestions [Haynes and Stone (198.V), Murray and Ginman (1975)] are worth consideration but need to be verified in the light of the experience of other countries. Though Murray and Ginman (1975) have suggested price separation format for imports, we apply this format to export functions for Pakistan. The purpose of the paper is first, to examine the price separation format in order to see how far the format corresponds to Pakistan's exports. Second, is to examine supply-price specification suggested by Haynes

\footnotetext{
${ }^{*}$ Lecturer, Department of Economics, Gomal University, D.I.Khan
} 
and Stone (1983). Studies on the import and export behaviour of Pakistan [Khan (1974). Naqvi et al (1983). Sarmad (1985). Anwar (1985), and Khan and Saqib (1993)] have not investigated the above aspects.

The remainder of the paper is structured as follows. Section II specifies the export functions for Pakistan in the light of these views. Section III deals with results and discussions and the final section is devoted to conclusions.

\section{Traditional Export Functions}

The demand for exports depends on the world or important trade partners' income and also on the competition of domestic export prices with the world or important trade partners' export prices. Similarly, supply of exports is determined by the domestic price of exports, domestic economic performance proxied by the GDP and domestic price level. It is assumed that $\mathrm{Xd}=\mathrm{Xs}$. Therefore, in $\log$ linear form the following are the demand and supply equations for exports. Equations 1 and 2 are the traditional form of the export demand and supply respectively.

$\operatorname{LnXd}=\alpha_{0}+\alpha_{1} \operatorname{LnPU}+\alpha_{3} \operatorname{LnZW}$

$\operatorname{LnXs}=\beta_{0}+\beta_{1} \operatorname{LnZZ}+\beta_{2} \operatorname{LnYpak}$

Since the equations are specified in logarithm, the coefficients are elasticities. The expected signs of the coefficients are $\alpha_{1}<0, \alpha_{3}>0, \beta_{1}>0$, $\beta_{2}>0$.

\section{Export Demand Function}

The relative price variables (PLJ and ZZ) of the traditional form in the above equations are separated and a dummy (Do) has been added to see the impact of trade liberalisation efforts on export demand (Equations 3 and 4) and export supply (Equations 5 and 6) which Pakistan has been pursuing vigorously since the beginning of the 1990s [see Pakistan Economic Survey (PES) 1992 and later years]. The new equations are as follows.

$$
\begin{aligned}
& \operatorname{LnXd}=\delta_{0}+\delta_{1} \operatorname{LnPXd}+\delta_{2} \operatorname{Ln} \mathrm{XW}+\delta_{3} \mathrm{LNZW} \\
& \operatorname{LnXd}=\zeta_{0}+\zeta_{1} \operatorname{LnPXd}+\zeta_{2} \operatorname{LnXW}+\zeta_{3} \mathrm{LNZW}+\zeta_{4} \text { Do }
\end{aligned}
$$

The expected signs of the coefficients in Equations 3 and 4 are $\delta_{1} \zeta_{1}<0, \delta_{2} \zeta_{2}>0$ and $\delta_{3} \zeta_{3}>0$, and $\zeta_{4}$ may be positive or negative. 


\section{Export Supply Functions}

$$
\begin{aligned}
& \text { LnXs }=\theta_{0}+\theta_{1} \operatorname{LnPXpak}+\theta_{2} \operatorname{Ln} \text { Pd }+\theta_{3} \text { LnYpak } \\
& \text { LnXs }=\kappa_{0}+\kappa_{1} \operatorname{LnPXpak}+\kappa_{2} \operatorname{Ln} \text { Pd }+\kappa_{3} \text { LnYpak }+\kappa_{4} \text { Do }
\end{aligned}
$$

The expected signs of the coefficients for the export supply price and GDP are positive, while for domestic price level it is negative and the dummy has an unknown sign.

\section{Supply Price Specification}

We investigate the Haynes and Stone (1983) argument that dynamic supply-price be used as a dependent variable to study the behaviour of exports. This study explores both static and dynamic versions of the above suggestion. Moreover, liberalisation dummy Do has been added to the static version to see the impact of liberalisation on export behaviour if the supplyprice specification is desirable. Thus the equations are as follows:

$$
\begin{aligned}
& \operatorname{LnPXpak}=\lambda_{0}+\lambda_{1} \operatorname{LnX}+\lambda_{2} \operatorname{LnPd}+\lambda_{3} \operatorname{LnYpak} \\
& \operatorname{LnPXpak}=\mu_{0}+\mu_{1} \operatorname{LnX}+\mu_{2} \operatorname{LnPd}+\mu_{3} \operatorname{LnYpak}+\mu_{4} \text { Do } \\
& \operatorname{LnPXpak}=\eta_{0}+\eta_{1} \operatorname{LnX}+\eta_{2} \operatorname{LnPd}+\eta_{3} \operatorname{LnYpak}+\eta_{4} \operatorname{LnPXpak~(-1)~}
\end{aligned}
$$

The expected signs of the coefficients are: $\lambda_{1}, \mu_{1}, \eta_{1}>0, \lambda_{2}, \mu_{2}$, $\eta_{2}>0, \lambda_{3}, \mu_{3}, \eta_{3}>0, \eta_{4}>0$ and the sign of . $\mu_{4}$ is uncertain.

Where

$\mathrm{Xd}=$ real value of exports demanded, $\mathrm{Xs}=$ real value of export supply, $\mathrm{X}=$ total exports, PXd $==$ Unit value of exports of Pakistan in US dollars, $\mathrm{XW}=$ Unit value of exports of the world in US dollars, $\mathrm{PU}=$ $\mathrm{PXd} / \mathrm{XW}, \mathrm{ZW}=$ world real income, PXpak= Unit value of exports of Pakistan in domestic currency rupees [Rs.], $\mathrm{Pd}=$ Wholesale Price Index (WPI) of Pakistan, ZZ= PXpak/Pd, Ypak ${ }^{=}$real GDP of Pakistan.

All the data on GDP, and exports have been taken from Pakistan Economic Survey (various issues). Real World Income data have been taken from World Tables (various issues). The data regarding export unit value index for both Pakistan and the world in US\$, world Whole Sale Price Index (WPI), and unit value of exports in domestic currency have been taken from International Financial Statistics (IFS) yearbooks [various years]. The variables are at $1990=100$ prices. 


\section{Results and Discussion}

Table 1 shows the results of demand for exports (Equations 1, 3 and 4) in OLS and TSLS. The instruments used in TSLS include: constant, lagged [GDP, exports, agriculture, industry, world income, total, primary, manufactured and semi-manufactured exports, world and Pakistan export prices]. Consumer Price Index, Wholesale prices of the world and Pakistan, growth of world income, dummy, GDP deflator, and imports.

Where necessary first order autocorrelation were corrected adding $A R(1)$ at the end of the equation specification for both OLS and TSLS. Autocorrelation has no universal cure.

Different methods suggested in econometrics literature have their own limitations. Several considerations in obtaining consistent estimates in the case of autocorrelation in TSLS are discussed in Fair (1970). Fair has shown that lagged dependent and independent variables must be in the instruments list to obtain consistent estimates .The signs of the relative price variable and the world income (Table 1) are correct and significant (Equation 1). This is in agreement with Khan (1974) results that also have significant price (-1.84) and world income (0.92) coefficients. Equations 3 and 4 with a dummy have correct and expected signs and show the importance of the relative price separation format.

Table 1: Export - Demand

\begin{tabular}{lcccccc}
\hline Equation & \multicolumn{2}{c}{ Equation I } & \multicolumn{2}{c}{ Equation-3 } & \multicolumn{2}{c}{ Equation-4 } \\
\hline Variables & OLS & TSLS & OLS & TSLS & OLS & TSLS \\
Constant & -29.30 & -15.15 & -33.49 & -42.84 & -28.95 & -74.92 \\
& $(-4.74)^{*}$ & $(-1.25)$ & $(-3.06)^{*}$ & $(-1.81)^{* *}$ & $(-2.30)$ & $(-2.09)$ \\
PU & -0.43 & -1.32 & - & - & - & - \\
& $(-2.35)^{*}$ & $(-1.88)^{* *}$ & & & & \\
ZW & 2.28 & 1.44 & 2.58 & 3.32 & 2.28 & 5.55 \\
& $(6.13)^{*}$ & $(1.99)^{* *}$ & $(3.54)^{*}$ & $(2.05)^{*}$ & $(2.73)^{*}$ & $(2.30)^{*}$ \\
Do & - & - & - & - & 0.14 & -0.95 \\
& & & & & $(0.80)$ & $(-1.60)$ \\
PXd & - & - & -0.46 & -1.18 & -0.43 & -2.26 \\
& & & $(-1.61)$ & $(-2.07)^{*}$ & $(-1.52)$ & $(-1.78)^{* *}$ \\
XW & - & - & 0.31 & 0.36 & 0.34 & 0.48 \\
& & & $(0.81)$ & $(0.42)$ & $(0.85)$ & $(0.46)$ \\
$\mathrm{R}^{\prime 2}$ & .97 & 0.95 & 0.96 & 0.95 & 0.96 & 0.87 \\
D.W & 1.40 & 1.54 & 1.40 & 1.57 & 1.41 & 1.65 \\
\hline
\end{tabular}

Note: Number in Parentheses are t-statistics where $*$ and ${ }^{* *}$ indicate significance at $5 \%$ and $10 \%$ respectively. 
Domestic price index of exports is significant but world index of exports is not significant. This implies that prices of the domestic exports have a dominant effect on exports demand while in relative price format we do not get such important information that has tremendous bearing on export policies. Equation 3 shows the results of the separation of the relative price variable $(\mathrm{PXd} / \mathrm{Pd})$ in both OLS and TSLS.

Domestic price index is significant in TSLS and world income in both OLS and TSLS, whereas world price index is insignificant in both estimations. This implies that domestic price of exports is more important than world prices and this also points out the fact that domestic prices and world income are more important and dominant determinants of export demand. For export promotion attention is given to such factors. We do not obtain such important information in the traditional form of export demand, which has a tremendous bearing on export policies. Thus the study of export-demand in price-separation format is desirable.

In Equation 4 when the liberalistion dummy is added, we get different results in OLS and TSLS and both are not significant. Though the two results contradict each other, the obvious fact is that liberalistion does not have too bad an effect on demand for exports. Adjusted $\mathrm{R}^{2}$ and D.W. are satisfactory showing statistical fit and reliability of the equation.

Tables 2 and 3 show the various forms of the export supply function. Total export supply function in traditional form [Equation 2] is positively sloped and although the relative price is positive it is not significant. Khan and Saqib (1993) also obtained a positive but not significant coefficient $(0.10)$. The positive and not significant coefficient implies that supply price is not important, that is Pakistan is a price taker. This is in accordance with economic theory that tells us that small countries are price takers. Their actions cannot influence the rest of the world [Dun and Ingram (1996)]. The significant coefficient for real GDP implies that the health of the economy plays a more dominant role than the supply price of exports in the traditional form.

In Equation 5 when the relative price variable $(\mathrm{ZZ}=\mathrm{Pxpak} / \mathrm{Pd})$ is separated we get very important information on the determinants of export supply. Domestic supply of exports (Pxpak) turns out to be significant in TSLS, a result in accordance with economic theory. The negative and significant domestic price level suggests the importance of domestic inflation in influencing the supply of exports. Because of high inflation Pakistan's exports lose international competitiveness. To make exports more competitive, the domestic inflation rate has to be managed 
within reasonable limits. Equation 6 shows that liberalisation has significant and positive influence on export supply while the relative price variable is significant at the $10 \%$ level. The signs of both domestic supply price (Pxpak) and domestic price level (Pd) are correct and according to expectations.

Table 2: Export- Supply

\begin{tabular}{lcccccc}
\hline Equations & \multicolumn{2}{c}{ Equation 2 } & \multicolumn{2}{c}{ Equations 5 } & \multicolumn{2}{c}{ Equation 6 } \\
\hline Variables & OLS & TSLS & OLS & TSLS & OLS & TSLS \\
\hline Constant & -2.40 & -8.39 & -8.19 & -21.65 & -6.959 & -16.71 \\
& $(-3.02)^{*}$ & $(-5.60)^{*}$ & $(-4.02)^{*}$ & $(-4.56)^{*}$ & $(-4.07)^{*}$ & $(-4.92)^{*}$ \\
ZZ & 0.29 & 0.26 & - & - & - & - \\
& $(1.58)$ & $(1.18)$ & & & & \\
Ypak & 1.25 & 1.27 & 2.20 & 2.50 & 2.05 & 2.09 \\
& $(11.97)^{*}$ & $(11.37)^{*}$ & $(6.75)^{*}$ & $(5.71)^{*}$ & $(7.73)^{*}$ & $(6.83)^{*}$ \\
Do & - & - & - & - & 0.24 & 0.24 \\
& & & & & $(2.51)^{*}$ & $(2.30)^{*}$ \\
Pxpak & - & - & 0.21 & 0,12 & 0.34 & 0.35 \\
& & & $(1.65)$ & $(0.73)$ & $(2.79)^{*}$ & $(2.12)^{*}$ \\
Pel & - & - & -0.75 & -0.84 & -0.91 & -0.95 \\
& & & $(-3.47)^{*}$ & $(-2.92)^{*}$ & $(-4.85)^{*}$ & $(-4.21)^{*}$ \\
W & 0.97 & 0.96 & 0.97 & 0.97 & 0.98 & 0.97 \\
D.W. & 1.40 & 1.40 & 1.54 & 1.56 & 1.60 & 1.61 \\
\hline
\end{tabular}

Equations 7 and 8 (Table 3) show the results of Supply-Price specification suggested by Haynes and Stone (1983). This study has added the liberalisation dummy to the specification. For Equation 7 TSLS results are more reliable than OLS results. These results point out the importance of the study of exports in a simultaneous equation framework. TSLS results are correct and according to expectations. Export supply coefficient is positive but not significant in TSLS but significant in OLS. This implies that the volume of exports has a less powerful impact on export prices.

The domestic price index has the correct sign in TSLS though not significant. OLS and TSLS results contradict each other and the conclusion emerges that the health of the economy provided by GDP plays the most effective role in influencing the price of exports. Though the volume of exports and the domestic price index representing inflation have correct signs, they do not play a significant role in influencing the price of exports. Domestic economic conditions are the most important. When the 
liberalisation dummy is added in Equation 8, we get very inferior results as well as incorrect and unexpected results for the domestic price index. Liberalisation has a negative impact on the price of exports.

Table 3 Export Supply

\begin{tabular}{lcccccc}
\hline Equations & \multicolumn{2}{c}{ Equation -7 } & \multicolumn{2}{c}{ Equation-8 } & \multicolumn{2}{c}{ Equation-9 } \\
\hline Variables & OLS & TSLS & OLS & TSLS & OLS & TSLS \\
\hline Constant & 0.43 & -22.94 & -0.03 & -10.3 & 6.00 & -13.58 \\
& $(0.06)$ & $(-3.06)$ & $(-0.005)$ & $(-0.92)$ & $(1.55)$ & $(-0.74)$ \\
LnX & 0.23 & 0.24 & 0.29 & 0.38 & 0.42 & 1.32 \\
& $(1.70\}^{* *}$ & $(0.74)$ & $(1.97)^{*}$ & $(0.35)$ & $(2.80)$ & $(1.78)$ \\
LnYpak & -0.23 & 1.92 & -0.24 & 0.62 & -0.76 & 0.66 \\
& $(-0.34)$ & $(2.54)^{*}$ & $(-0.38)$ & $(0.43)$ & $(-1.83)$ & $(0.34)$ \\
Do & - & - & -0.21 & -0.65 & - & - \\
& & & $(-1.41)$ & $(-1.09)$ & & \\
Pd & 1.11 & -0.1 & 1.18 & 0.77 & 0.26 & -1.97 \\
& $(3.25)^{*}$ & $(-0.3)$ & $(3.61)^{*}$ & $(1.44)$ & $(1.52)$ & $(-2.23)$ \\
Pxpak(-1) & - & - & - & - & 0.86 & 1.52 \\
& & & & & $(8.17)$ & $(3.00)$ \\
$R^{2}$ & 0.98 & 0.98 & 0.98 & 0.98 & 0.98 & 0.95 \\
D.W. & 1.50 & 1.23 & 1.53 & 1.46 & 1.33 & 2.01 \\
\hline
\end{tabular}

Equation 9 shows the dynamic version of the supply-price response for exports. The results are highly satisfactory and the coefficients have the correct and expected signs. Exports supply, domestic price and lagged supply price of exports are significant. Domestic economic conditions, though not significant, have a positive impact on the supply price. The signs as well as the level of significance of the coefficients demonstrate that in the dynamic version of the supply-price response for exports, lagged year price of exports play a more dominant role than the domestic supply condition represented by the real GDP. Exporters give more attention to the last year exports prices. Lagged year exports in the traditional form of both exports demand and supply were significant, though this significance was much smaller for exports supply. Khan (1974) also obtained similar results for Pakistan for lagged exports. For export supply lagged exports supply had the coefficient $0.40(2.24)$ in TSLS. 


\section{Conclusions}

The signs of the relative price variable and world income are correct and significant in the traditional demand equation for total exports. The estimation results provide consistent estimates of the export demand and supply elasticities and are comparable to other studies. World income turns out to be a more significant factor than export prices. Liberalisation does not have too bad an effect on demand for total exports. Price separation format for export demand has the correct and expected signs and shows the importance of the format. Domestic price index of exports is significant but the world index of exports is not significant. This implies that prices of domestic exports have a dominant effect on exports demand while in relative price format we do not get such important information, which has a tremendous bearing on export policies. Lagged year exports have a significant influence on the demand for current exports.

Positively sloped total export supply function is in agreement with other studies. Liberalisation though not significant has a positive influence on total exports supply. In price separation form, domestic price level is negative and significant suggesting that domestic inflation plays a dominant role in export supply. To make exports more competitive, the domestic inflation rate has to be contained. This equation also documents that the format provides better estimates of export supply than the traditional relative price format. The importance of the price separation format also lies in the fact that the dummy is significant whereas in relative price format it is not significant though positive. Past export supply does influence current supply. These results confirm the Haynes and Stone observation that dynamic supply-price specification gives better results than quantity specification of exports behaviour. Moreover, OLS estimates are inferior to TSLS estimates. This indicates that the simultaneity bias of the single equation study of exports makes the results biased and inconsistent. 


\section{References}

Anwar, Sajad, 1985, "Export Functions for Pakistan," Journal of Applied Economics. Vo1.4. No.1, pp.29-34.

Arize, A., 1986, "The Supply and Demand for- Imports and Export in a Simultaneous Mode1," Pakistan Economic and Social Review, Vol.24, No.2, pp57-76.

Arize, A., 1988, "The Demand and Supply for Export in Nigeria in a Simultaneous Mode1," The Indian Economic Journal, Vol.35, No. 4, pp.33-43.

Bahmani-Oskooee. Mohsen, 1984, "On the Effect of Effective Exchange Rates on Trade Flows." Indian Journal of Economics. Vol.65, pp.57-67.

Bahmani-Oskooee, Mohsen, 1986, "The Determinants of International Trade Flows," Journal of Development Economics, pp. 107-123.

Balassa, B. et all, 1989, "The Determinants of Export Supply and Export Demand in Two Developing Countries: Greece and Korea," International Economic Journal, Spring, pp.1-16.

Dunn, R.M.and J.C.Ingram, 1996, International Economics, 4th Ed. John Wiley and Sons.

Dunlevy, James A., 1980, "A Test of the Capacity Pressure Hypothesis Within A Simultaneous Equation Model of Export Performance," Review of Economics and Statistics, Vo1.62, pp. 131-135.

Fair, R.C., 1970, "The Estimation of Simultaneous Equation Model With Lagged Endogenous Variables and First Order Serially Correlated Errors" Econometrica, Vol.38. pp. 507-516.

Godstein, M. and Mohsin S. Khan, 1978, "The Supply and Demand for Exports: A Simultaneous Approach," Review of Economics and Statistics, Vol.60. No.2 pp. 275-286.

Haynes, Sand J. Stone, 1983, "Specification of Supply Behaviour in International Trade," Review of Economics and Statistics, Vol.65, pp.626-631. 
116 The Lahore Journal of Economics, Vol.7, No.1

Houthakker. H.S. and Stephen Magee, 1969, "Income and Price Elasticities in World Trade," Review of Economics and Statistics, Vo1.51, pp.111-125.

IMF, International Financial Statistics (various issues), Washington D.C.

Khan, Mohsin S., 1974, "Import and Export Demand in Developing Countries,” IMF Staff Papers, Vo1. 21, pp. 678-693.

Khan, Ashfaque and Najam Saqib, 1993, "Exports and Economic Growth: Pakistan Experience” International Economic Journal, Vo1.7, No.3, pp.53-64.

Murray, Tracy and P.Ginman, 1976, "An Empirical Examination of the Traditional Aggregate Import Demand Model," Review of Economics and Statistics, Vo158, pp.75-80.

Naqvi et al, 1983, The PIDE Macro-econometric Model of Pakistan's Economy, Islamabad, Pakistan Institute of Development Economics (PIDE).

Pakistan, Government of, Pakistan Economic Survey [various issues], Islamabad, Ministry of Finance, Economic Advisor Wing.

World Bank, World Tables (various issues), Washington D.C. 